\title{
The Common Fibular Nerve (and its Branches) in Fetuses
}

\author{
El Nervio Fibular Comun (y sus Ramos) en Fetos
}

D. Chetty*; P. Pillay*; L. Lazarus* \& K. S. Satyapal*

\begin{abstract}
CHETTY, D.; PILlay, P.; LAZARUS, L. \& SATYAPAL, K. S. The common fibular nerve (and its branches) in fetuses. Int. J. Morphol., 32(2):455-460, 2014.

SUMMARY: The common fibular nerve (CFN), is a branch of the sciatic nerve ( $\mathrm{SN})$ that exits the popliteal fossa and is located at the tuberculum of the fibula. At the tuberculum of the fibula, the CFN bifurcates into deep (DFN) and superficial (SFN) fibular nerves. Forty fetuses were micro-dissected to (i) describe the course of the CFN in relation to the tuberculum and neck of the fibula in fetuses; (ii) describe the branches, distribution and relation of the DFN and SFN to muscles within the anterolateral compartment of the leg. The CFN, DFN and SFN were present in all specimens dissected; the CFN measured a mean length (mm) of 16.03 and 16.69 on the right and left sides respectively. Bifurcation of the CFN related to the tuberculum of fibula (right; left) - above 20/80 (25\%); 14/80 (17.5\%); below $6 / 80(7.5 \%) ; 10 / 80(12.5 \%)$ and at the tuberculum 54/80 (67.5\%); 56/80 (70\%). The DFN bifurcated into medial and lateral branches in $68 / 80(85 \%)$ and 54/80 (67.5\%) on the right and left sides, respectively. The SFN bifurcated into a medial branch in $78 / 80(97.5 \%)$ and $76 / 80(95 \%)$ on right and left sides, respectively and a lateral branch in 78/80 (97.5\%) and 76/80 (95\%) on right and left sides, respectively. The course and distribution of the CFN, DFN and SFN were consistent with the literature reviewed and descriptions found in standard anatomical textbooks. However, our findings show that the DFN has a variable number of branching patterns, which is unique to this fetal study and an intermediate branch of the SFN which was recorded in 3/80 cases.
\end{abstract}

KEY WORDS: Common fibular nerve; Deep fibular nerve; Superficial fibular nerve.

\section{INTRODUCCIÓN}

The common fibular nerve (CFN) is a branch of the sciatic nerve $(\mathrm{SN})$ that arises from the lumbosacral plexus (Standring et al., 2008). As the SN approaches the popliteal region it divides into a large tibial and smaller CFN that innervates the muscles of the lower limb. The tibial nerve (L4, L5, S1, S2, S3) passes deep to the soleus muscle innervating the musculature of the posterior compartment of the leg. The CFN (L4, L5, S1, S2) passes along the tuberculum of the fibula, dividing at the level of deep head of peroneus longus into a deep fibular nerve (DFN) and superficial fibular nerve (SFN).

The anterolateral compartments of the leg, foot, skin and muscles is innervated by the DFN and SFN (Dellon et al., 2002; Standring et al.). Narendiran et al. (2010) documented that the SFN coursed in the lateral, anterior and in both compartments of the leg. Difficulty arises when branching patterns differ from the ones recorded in standard textbooks (Sinnatamby, 2006; Standring et al.). The muscular and cutaneous distribution of the CFN and SFN is important during surgical procedures viz. arthroscopic knee surgery, tibial osteotomy and traction injuries (Ryan et al., 2003; Narendiran et al.). Damage to the CFN and SFN may result in foot drop (Ellis, 2010). During embryonic development the malformation (which include lesions of the anterior horn cells L4 and L5 roots) of the CFN, DFN and SFN can be related to the lack or limited movement experienced within the lower limb (Steward, 2008; Bas et al., 2012). An accurate description of the CFN and SFN and its branching patterns may decrease its risk of damage in clinical procedures outlined above (Narendiran et al.). Agthong et al. (2008) reported important data regarding the morphometric anatomy of the SFN and its branches to use it as a nerve graft. de Leeuw et al. (2010) reported that iatrogenic damage to the SFN is the most frequently reported complication in anterior ankle arthroscopy. This study was undertaken on fetuses to determine the anatomical variations of the $\mathrm{CFN}$ and its terminal branches viz. the DFN and the SFN.

"Department of Clinical Anatomy, School of Laboratory Medicine and Medical Sciences, College of Health Sciences, Westville Campus, University of KwaZulu-Natal, South Africa. 


\section{MATERIAL AND METHOD}

The study comprised of forty fetal specimens ( 80 sides) which were obtained from the Department of Clinical Anatomy, University of Kwazulu - Natal in accordance with the National Health Act no 61 of 2003. Ethical approval was granted by the relevant institutional authority (Ethical Clearance Approval Number: BE124/11). The following incisions were made to micro-dissect the skin using Grant's Dissector as a guide, a skin incision was made from the inferior gluteal sulcus. The second incision was made from the inferior border of the popliteal crease to tendocalcaneous. The skin was reflected laterally and downwards exposing the biceps femoris muscle, semimembranosus muscle, gastrocnemius muscle and neurovascular structures, which were identified and reflected laterally. The bifurcation of the SN in the popliteal fossa was identified using a probe. The CFN was traced along its course through the lateral compartment of the leg. The length, course and distribution of CFN were measured using a digitronic calliper (Wilson Wolpert Absolute series, Netherlands $110-15 \mathrm{DAB})$. The bifurcation of the CFN into DFN and SFN were identified using a probe.

\section{RESULTS}

The SN, CFN, DFN and SFN were present in all specimens ( $\mathrm{n}=80$ sides). The CFN coursed laterally and around the tuberculum of the fibula before exiting the popliteal fossa. The results will be depicted into two categories viz, Level of division and Branching pattern and number of branches.

Level of division. The level of bifurcation of the CFN occurred i) at the tuberculum of the fibula: $54 / 80(67.5 \%)$ and $56 / 80$ (70\%) on right and left sides, respectively (Figs. 1 and 2); ii) above the tuberculum of the fibula: 20/80 (25\%) on the right and $14 / 80(17.5 \%)$ on the left sides (Fig. 3); iii) below the tuberculum of the fibula: $6 / 80(7.5 \%)$ on the right and 10/80 $(12.5 \%)$ on the left sides, respectively (Fig. 4). The average length of the CFN from its point of origin viz. the sciatic nerve to its termination in relation to the tuberculum of the fibula was $16.03 \pm 3.53(11.01-22.77 \mathrm{~mm})$ and 16.69 $\pm 3.90(10.65-$ $24.14 \mathrm{~mm}$ ), on the right and left sides, respectively.

Branching pattern and number of branches. At the tuberculum of fibula, the CFN divided into two branches viz. DFN and SFN in 48/80 (60\%) and $30 / 80(37.5 \%)$ on right and left sides, respectively. The variation noted was: CFN divided into three branches in 32/80 (40\%) and 50/80 $(62.5 \%)$ on right and left sides, respectively (Fig. 5).

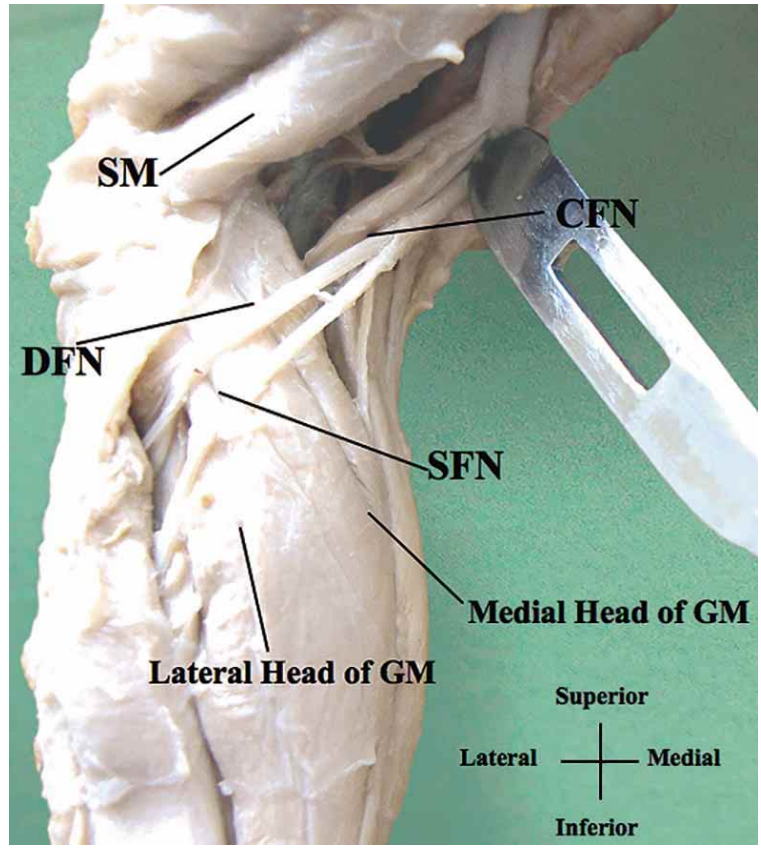

Fig. 1. Lateral view of leg showing bifurcation of the CFN. $\mathrm{CFN}=$ Common fibular nerve, $\mathrm{DFN}=$ Deep fibular nerve, $\mathrm{SFN}=$ Superficial fibular nerve, $\mathrm{GM}=$ Gastrocnemius muscle, $\mathrm{SM}=$ Semimembranosus muscle.

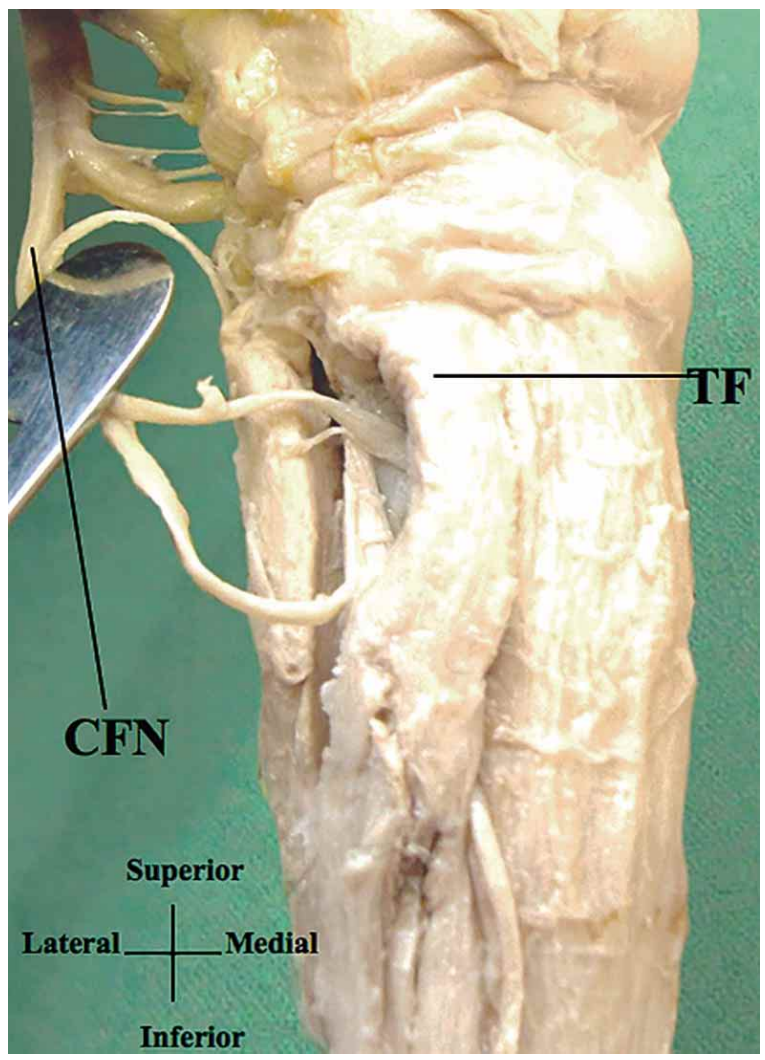

Fig. 2. Bifurcation of the CFN at the tuberculum of fibula (Anterolateral view). $\mathrm{CFN}=\mathrm{Common}$ fibular nerve, $\mathrm{TF}=$ Tuberculum of fibula. 


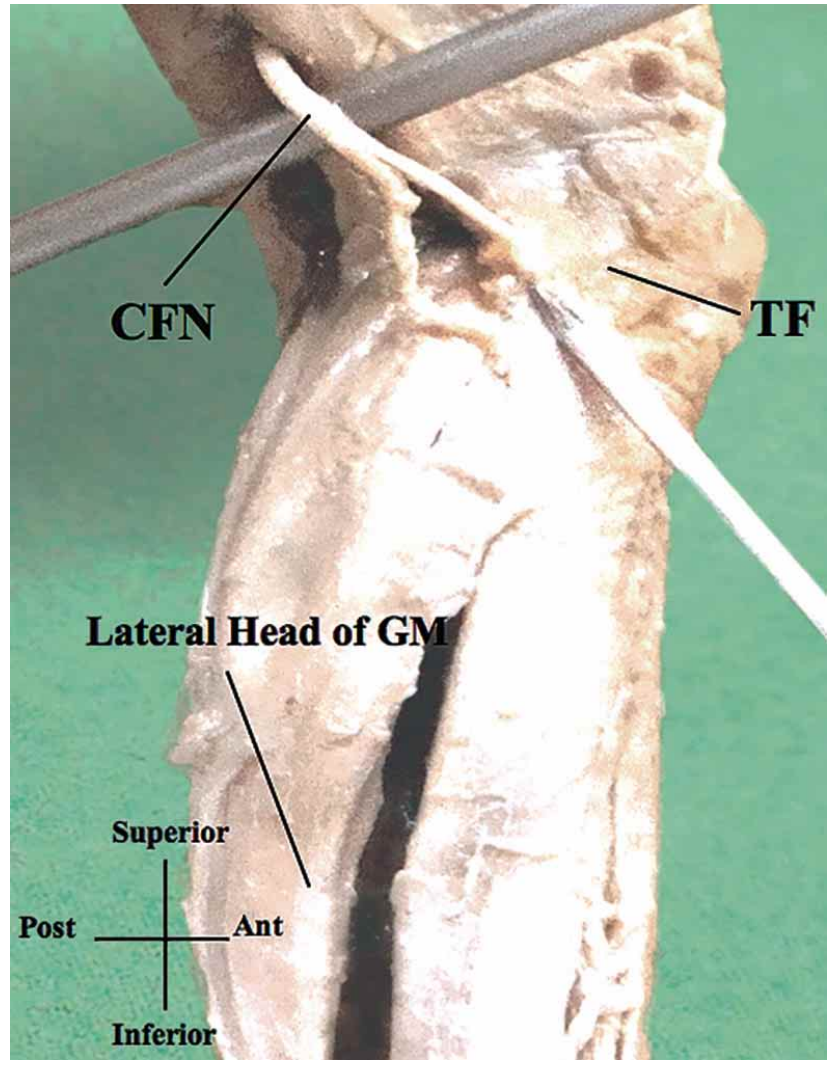

Fig. 3. Lateral view illustrating the CFN bifurcating above the tuberculum of fibula. $\mathrm{CFN}=\mathrm{Common}$ fibular nerve, $\mathrm{TF}=$ Tuberculum of fibula, GM= Gastrocnemius muscle.

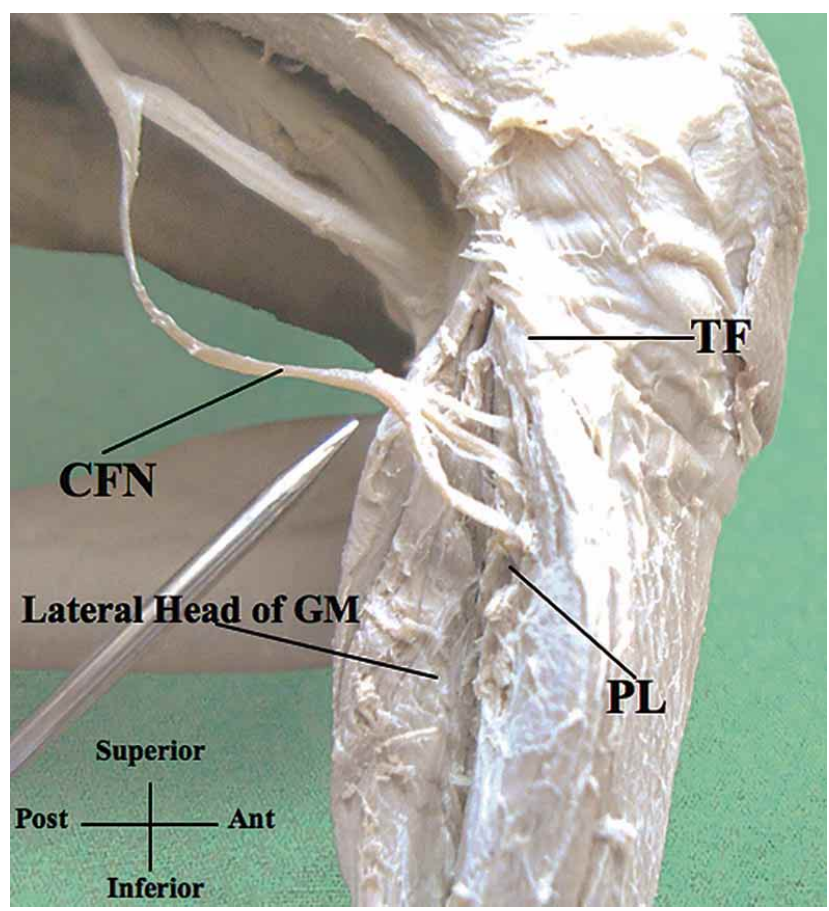

Fig. 5. Lateral view showing the CFN dividing into three branches. $\mathrm{CFN}=$ Common fibular nerve, $\mathrm{TF}=$ Tuberculum of fibula, $\mathrm{GM}=$ Gastrocnemius muscle, $\mathrm{PL}=$ Peroneus longus.

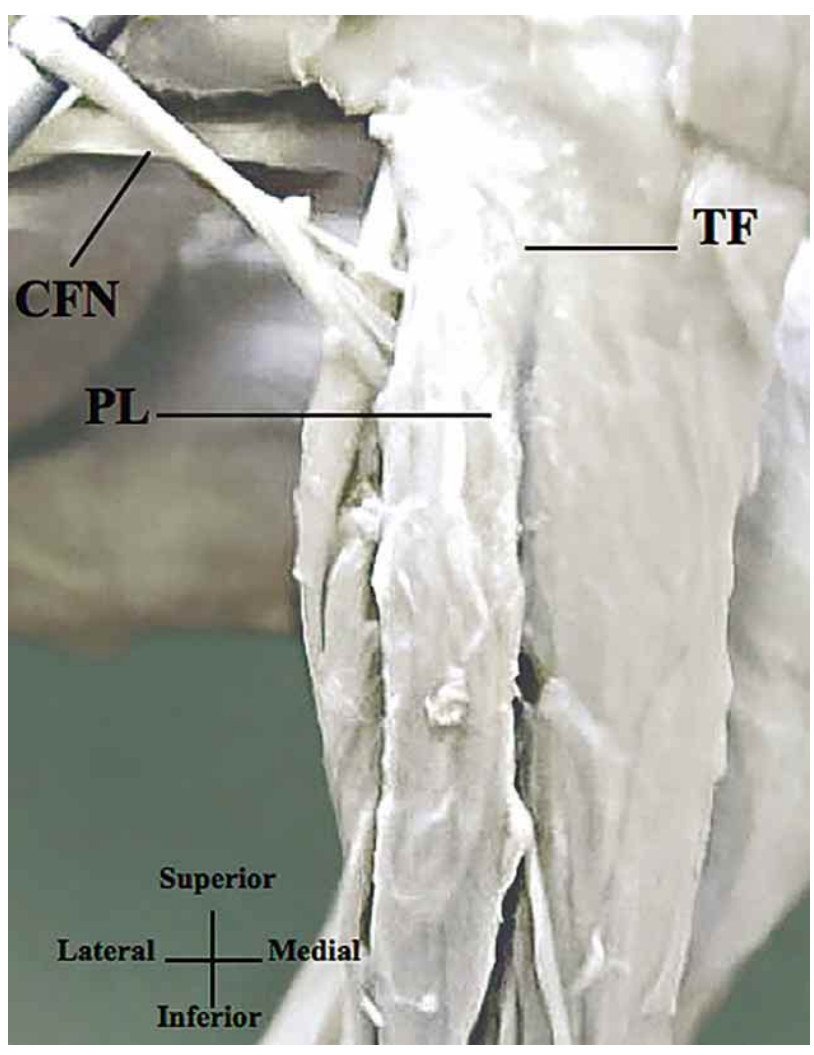

Fig. 4. Bifurcation of the CFN below the tuberculum of fibula (Anterolateral view). $\mathrm{CFN}=\mathrm{Common}$ fibular nerve, $\mathrm{TF}=$ Tuberculum of fibula, $\mathrm{PL}=$ Peroneus longus.

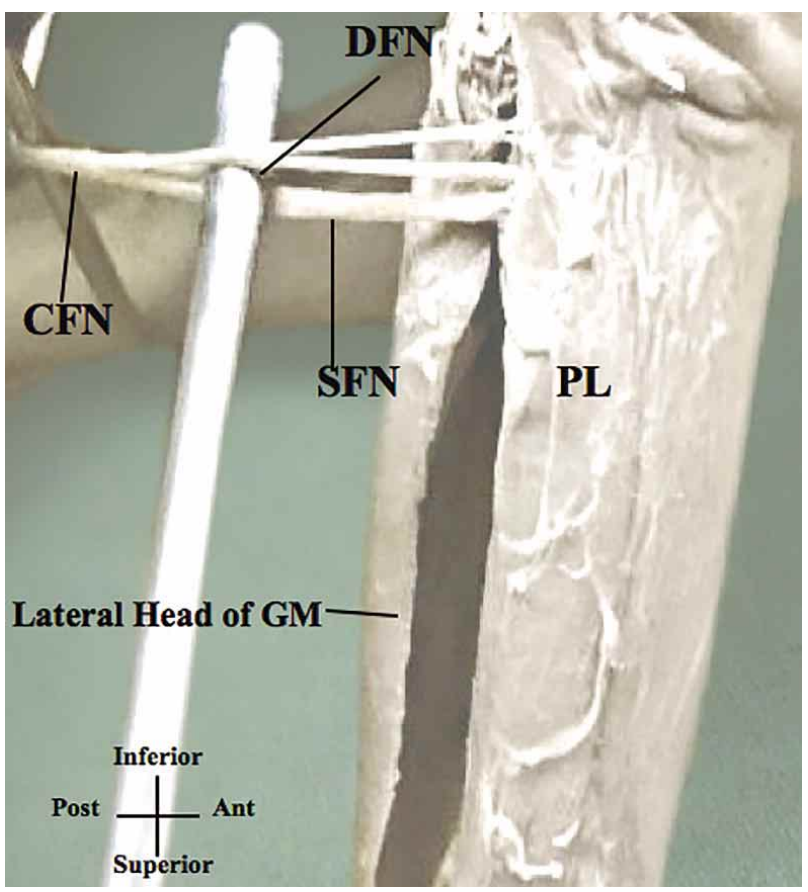

Fig. 6. Anterolateral view of the DFN bifurcating into medial and lateral branches. $\mathrm{CFN}=\mathrm{Common}$ fibular nerve, $\mathrm{SFN}=$ Superficial fibular nerve, $\mathrm{DFN}=$ Deep fibular nerve, $\mathrm{PL}=$ Peroneus longus, $\mathrm{GM}=$ Gastrocnemius muscle. 


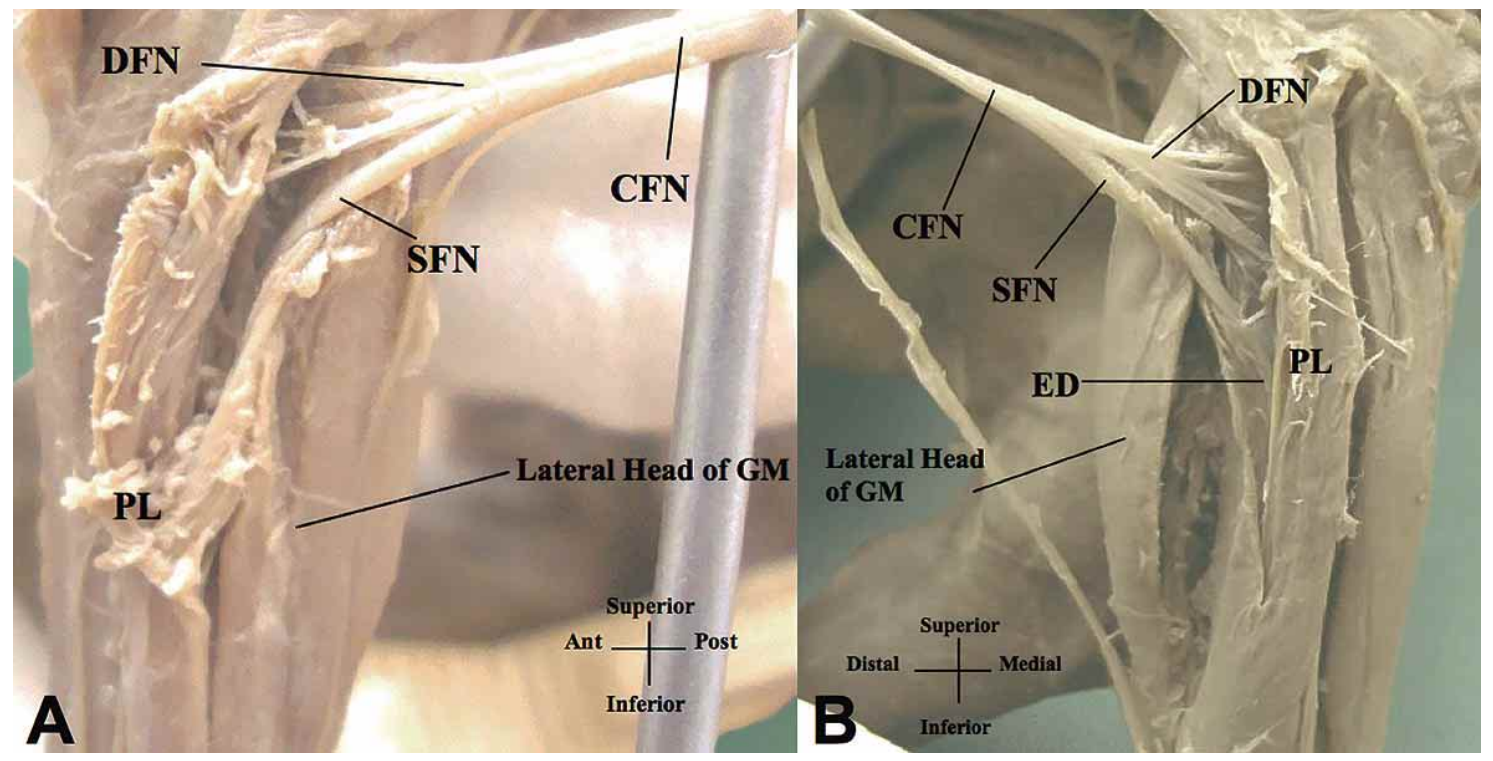

Fig. 7. A. Anterolateral view of the DFN dividing into four branches. B. Lateral view of the DFN dividing into three branches. $\mathrm{DFN}=$ Deep fibular nerve, $\mathrm{SFN}=$ Superficial fibular nerve, $\mathrm{CFN}=\mathrm{Common}$ fibular nerve, $\mathrm{PL}=\mathrm{Peroneus}$ longus, $\mathrm{GM}=$ Gastrocnemius muscle, $\mathrm{ED}=$ Extensor digitorum muscle.

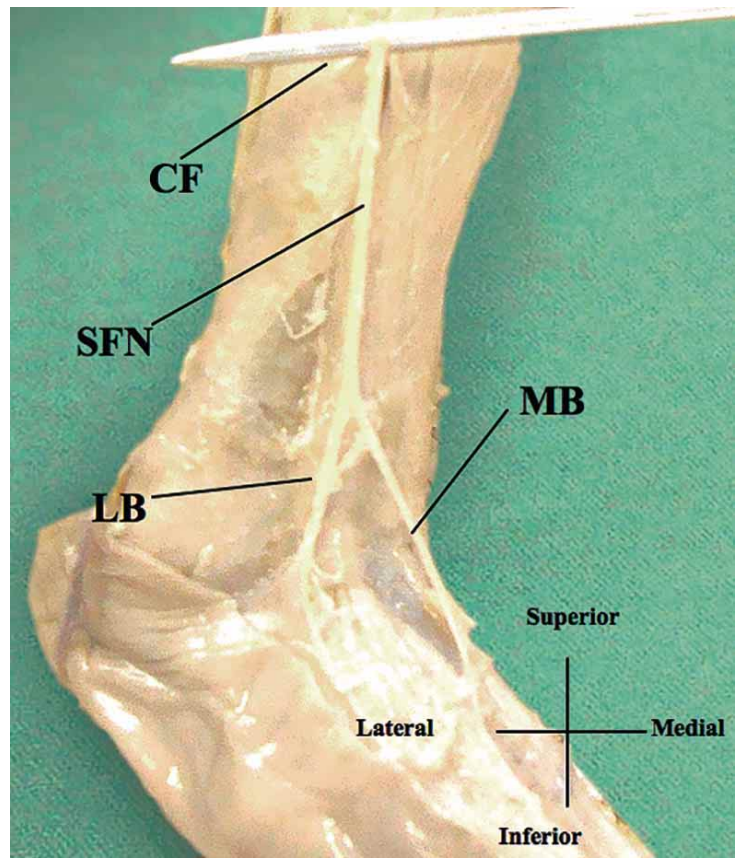

DFN arose from CFN and continued as a single trunk in $68 / 80(85 \%)$ and $54 / 80(67.5 \%)$ on the right and left sides, respectively (Fig. 6). The variations noted were: i) DFN arose as a single trunk from the CFN and bifurcated into two branches in: $10 / 80(12.5 \%)$ and $24 / 80(30 \%)$ on the right and left sides, respectively; ii) DFN arose as a single trunk from the CFN and divided into three branches in $2 / 80$ (2.5\%; left side only) and four branches in 2/80 (2.5\%; right side only) of cases (Fig. 7).

The SFN bifurcated bilaterally into medial and lateral branches with a similar frequency viz. 78/80 (97.5\%) and 76/80 (95\%) on right and left sides, respectively (Fig. 8). The variations noted were: i) SFN branched after perforating the peronei and extensor digitorum muscles in $6 / 80(7.5 \%)$ and $2 / 80(2.5 \%)$ on right and left sides, respectively (Fig. 9). ii) SFN bifurcated into medial, lateral and intermediate branches: this occurred in 2/80 $(2.5 \%)$ and $4 / 80(5 \%)$ on right and left sides, respectively (Fig. 10, Table I).

Fig. 8. Lateral view of the SFN bifurcating into a medial and lateral branch. $\mathrm{CF}=$ Crural fascia, $\mathrm{SFN}=$ Superficial fibular nerve, $\mathrm{MB}=$ Medial branch of $\mathrm{SFN}, \mathrm{LB}=$ Lateral branch of SFN.

Table I. The varying branching patterns of CFN, DFN and SFN.

\begin{tabular}{|c|c|c|c|c|c|c|c|c|}
\hline \multirow[t]{2}{*}{ Nerve } & \multicolumn{2}{|c|}{ One branch } & \multicolumn{2}{|c|}{ Two branches } & \multicolumn{2}{|c|}{ Three branches } & \multicolumn{2}{|c|}{ Four branches } \\
\hline & Right & Left & Right & Left & Right & Left & Right & Left \\
\hline CFN & --- & --- & ${ }_{80}^{48 /}(60 \%)$ & $30 / 80(37.5 \%)$ & ${ }^{32 /}{ }_{80}(40 \%)$ & ${ }^{50 /}{ }_{80}(62.5 \%)$ & --- & \\
\hline DFN & $68 / 80(85 \%)$ & $54 / 80(67.5 \%)$ & $10 / 80(12.5 \%)$ & $24 / 80(30 \%)$ & --- & ${ }_{80}^{2 /}(2.5 \%)$ & $2 / 80(2.5 \%)$ & --- \\
\hline SFN & & - & -- & --- & $2 / 80(2.5 \%)$ & $4 / 80(5 \%)$ & --- & \\
\hline Medial Side & & & ${ }^{78 / 80}(97.5 \%)$ & ${ }^{76} / 80(95 \%)$ & -.- & -- & --- & \\
\hline Lateral Side & & & $78 / 80(97.5 \%)$ & ${ }^{76}{ }_{80}(95 \%)$ & -- & --- & & \\
\hline
\end{tabular}




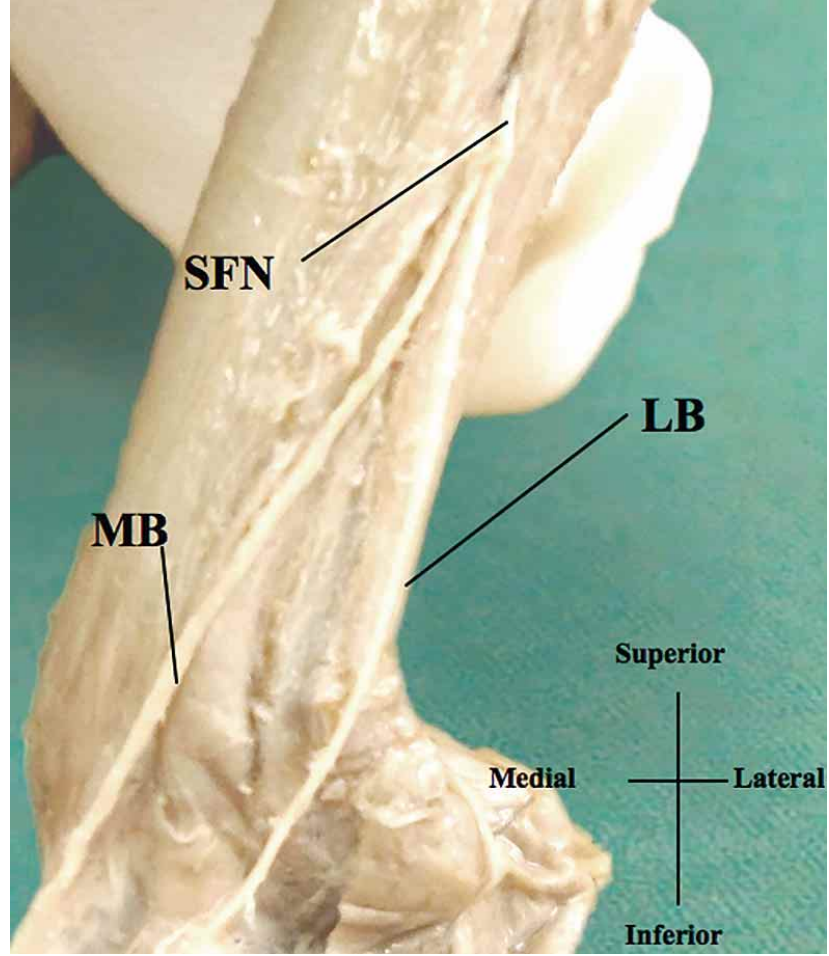

Fig. 9. Lateral view of bifurcation of the SFN after piercing peroneus longus muscles. $\mathrm{SFN}=$ Superficial fibular nerve, $\mathrm{MB}=$ Medial branch of SFN, LB= Lateral branch of SFN.

\section{DISCUSSION}

Our study conformed to the descriptions in standard anatomical texts (Standring et al.). However, the study is unique in that it describes variations in fetuses with regard to both their branching patterns as well as the levels at which the branching occurs. Deutsch et al. (1999) reported variability in the levels at which the CFN bifurcates. They found that in $81.4 \%$ of cases, the CFN bifurcated at the tuberculum of the fibula, $8.6 \%$ below and $10 \%$ above. Our findings correlate with these results.

According to standard anatomical textbook descriptions, the DFN enters the anterior compartment of the leg as a single branch (Sinnatamby; Standring et al.). However, our findings show that the DFN has a variable number of branching patterns. This variation appears to be unique in this fetal study. According to Gloobe \& Chain (1973) and Jeyaseelan (1989), the fascia at the entrance to the fibular tunnel is found between soleus and peroneus longus muscles. Ryan et al. documented that the DFN may be compressed during its course along the fibrous arches, leading to the impingement of the nerve. The varying branching patterns of the DFN in this study may influence its course and avoid entrapment within the fibular tunnel.

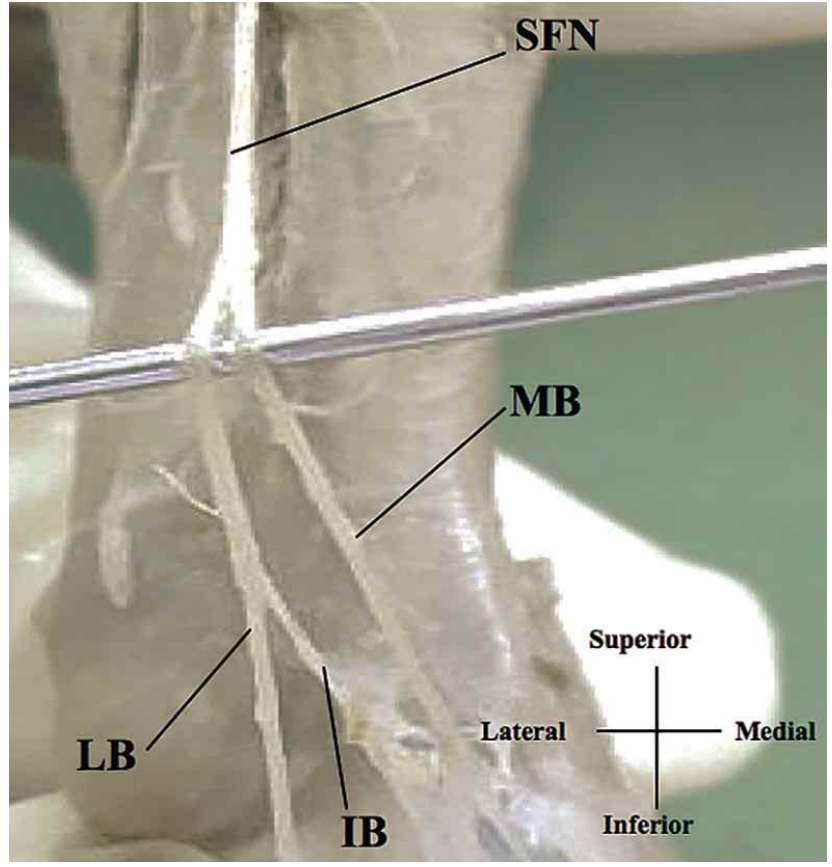

Fig. 10. Anterolateral view of the SFN dividing into three branches. $\mathrm{SFN}=$ Superficial fibular nerve, $\mathrm{MB}=$ Medial branch of SFN, $\mathrm{LB}=$ Lateral branch of SFN.

In the current study, the SFN coursed only within the lateral compartment of the leg in $92.5 \%$ and $97.5 \%$ on the right and left sides, respectively concurring with studies by Apaydin et al. (2008) and Narendiran et al. Our study also reports on an intermediate branch of the SFN in 3/80 cases; this compares favorably with that reported by Bas et al.

Our study also describes the location where the branching of the SFN occurred viz. before the nerve pierced the crural fascia (right $7.5 \%$ and left $2.5 \%$, respectively). This finding concurs with descriptions reported by Anthong et al., who also suggested that the SFN bifurcated either before the crural fascia in $28.2 \%$ of cases. The SFN and its terminal branches can be impinged during its course through the deep fascia resulting in entrapment syndrome (Lowdon, 1985; Nagabhooshana et al., 2009). The reason for the different patterns and piercing levels of the aforementioned nerves may be the effect of the elongating extremity during aging that enforces the fascia and modifies its position with the nerve, which is a more stable structure (Kurtoglu et al., 2006).

\section{CONCLUSION}

Even though the anatomy of the $\mathrm{CFN}$ has been well described in textbooks, many of these use adult cadavers as their sample (Sinnatamby; Standring et al.). Bearing this in 
mind, this fetal study on the CFN conformed to textbook descriptions with regard to its course and distribution. However, variations exist in the levels of bifurcation and branching patterns of the CFN, DFN and SFN. Knowledge of these variations in early ages may benefit pediatric surgeons, in planning for surgical intervention around the leg, ankle and foot.

CHETTY, D.; PILlAY, P.; LAZARUS, L. \& SATYAPAL, K. S. El nervio fibular comun (y sus ramos) en fetos. Int. J. Morphol., 32(2):455460, 2014.

RESUMEN: El nervio fibular común (NFC), es un ramo del nervio ciático (NC) que sale de la fosa poplítea y se ubica a nivel del tubérculo fibular. En el tubérculo fibular, el NFC se bifurca en los nervios fibular profundo (NFP) y superficial (NFS). Cuarenta fetos fueron micro disecados para (i) describir el curso del NFC en relación con el tubérculo y cuello de la fíbula en fetos; (ii) describir los ramos, distribución y relación del NFP y NFS con los músculos dentro del compartimento anterolateral de la pierna. El NFC, NFP y NFS estuvieron presentes en todos los especímenes disecados; el NFC midió una longitud promedio de 16,03 y 16,69 (mm) en el lado derecho e izquierdo, respectivamente. La bifurcación del NFC se relacionó con el tubérculo fibular del lado derecho e izquierdo: por encima en $25 \%$ y $17,5 \%$; por debajo $7,5 \%$ y 12,5 $\%$ y en el tubérculo $67,5 \%$ y $70 \%$. El NFP se bifurcó en ramos medial y lateral en un $85 \%$ en el lado derecho y $67,5 \%$ en el izquierdo. El NFS se bifurcó en una ramo medial en el $97,5 \%$ y $95 \%$ en los lados derecho e izquierdo, respectivamente, y un ramo lateral en el $97,5 \%$ y $95 \%$ del lados derecho e izquierdo, respectivamente. El curso y distribución del NFC, NFP y NFS coincidieron con la literatura revisada y textos de anatómia normal. Sin embargo, observamos que el NFP tiene un número variable de patrones de ramificación, único para este estudio fetal y un ramo intermedio del NFS que fue vista en $3 / 80$ casos.

PALABRAS CLAVE: Nervio fibular común; Nervio fibular profundo; Nervio fibular superficial.

\section{REFERENCES}

Agthong, S.; Huanmanop, T.; Sasivongsbhakdi, T.; Ruenkhwan, K.; Piyawacharapun, A. \& Chentanez, V. Anatomy of the superficial peroneal nerve related to the harvesting for nerve graft. Surg. Radiol. Anat., 30(2):145-8, 2008.

Apaydin, N.; Basarir, K.; Loukas, M.; Tubbs, R. S.; Uz, A. \& Kinik, H. Compartmental anatomy of the superficial fibular nerve with an emphasis on fascial release operations of the leg. Surg. Radiol. Anat., 30(1):47-52, 2008.

Bas, O.; Bilgic, S.; Salbacak, A.; Sonmez, O. F. \& Erkut, A. Variations of the superficial peroneal nerve and its terminal branches in the Turkish newborn fetuses. Turk. Neurosurg., 22(1):62-7, 2012.

de Leeuw, P. A.; Golanó, P.; Sierevelt, I. N. \& van Dijk, C. N. The course of the superficial peroneal nerve in relation to the ankle position: anatomical study with ankle arthroscopic implications. Knee Surg. Sports Traumatol. Arthrosc., 18(5):612-7, 2010.

Dellon, A. L.; Ebmer, J. \& Swier, P. Anatomic variations related to decompression of the common peroneal nerve at the fibular head. Ann. Plast. Surg., 48(1):30-4, 2002.

Deutsch, A.; Wyzykowski, R. J. \& Victoroff, B. N. Evaluation of the anatomy of the common peroneal nerve. Defining nerve-at-risk in arthroscopically assisted lateral meniscus repair. Am. J. Sports Med., 27(1):10-5, 1999.

Gloobe, H. \& Chain, D. Fibular fibrous arch. Anatomical considerations in fibular tunnel syndrome. Acta Anat. (Basel), 85(1):84-7, 1973.

Jeyaseelan, N. Anatomical basis of compression of common peroneal nerve. Anat. Anz., 169(1):49-51, 1989.

Kurtoglu, Z.; Aktekin, M. \& Uluutku, M. H. Branching patterns of the common and superficial fibular nerves in fetus. Clin. Anat., 19(7):621-6, 2006.
Lowdon, I. M. Superficial peroneal nerve entrapment. A case report. $J$. Bone Joint Surg. Br., 67(1):58-9, 1985.

Nagabhooshana, S.; Vollala, V. R.; Rodrigues, V. \& Rao, M. Anomalous superficial peroneal nerve and variant cutaneous innervation of the sural nerve on the dorsum of the foot: a case report. Cases J., 2:197, 2009.

Narendiran, K.; Rao, M.; Somayagji, S. N.; Koshy, S. \& Rodrigues, V. Clinical important anatomical variation of cutaneous branches of superficial fibular nerve in foot. Open Anat. J., 2:1-4, 2010.

Ryan, W.; Mahony, N.; Delaney, M.; O'Brien, M. \& Murray, P. Relationship of the common peroneal nerve and its branches to the head and neck of the fibula. Clin. Anat., 16(6):501-5, 2003.

Sinnatamby, C. S. Last's Anatomy: Regional and Applied. 11th ed. London, Churchill Livingstone, 2006. pp.249-89.

Standring, S. Gray's Anatomy. The Anatomical basis of Clinical Practice. $40^{\text {th }}$ ed. Illinois, Churchill Livingstone, 2008. pp.1471-2, 1495-505.

Steward, J. D. Foot drop: where, why and what to do? Pract. Neurol., 8(3):158-69, 2008.

Correspondence to:

Professor KS Satyapal

Department of Clinical Anatomy

College of Health Sciences

School of Laboratory Medicine and Medical Science

University of KwaZulu-Natal

Private Bag X54001

Durban 4000

SOUTH AFRICA

Email: satyapalk@ukzn.ac.za

Received: 04-12-2013

Accepted: 11-04-2014 